\title{
Development of Traditional Culinary Tourism Potential for Tourist Attraction in Lombok
}

\author{
Ayu Nurwitasari \\ Sekolah Tinggi Ilmu Administrasi Mandala Indonesia \\ Jakarta, Indonesia \\ ayunurwitasari@yahoo.com
}

\author{
Sri Fajar Ayuningsih \\ Sekolah Tinggi Pariwisata Bandung \\ Bandung, Indonesia \\ fajarayu36@gmail.com
}

\begin{abstract}
Diversity of traditional culinary in Lombok, West Nusa Tenggara, become a great potential to be developed as supporting services in the development of a tourist attraction. Culinary tourism be an alternative choice besides other types of travel such as cultural tourism, nature tourism and nautical tourism which has been first known by tourists who have visited Lombok. Culinary diversity owned Lombok, West Nusa Tenggara has not been taken seriously, but has great potential to be developed into a tourist attraction. The purpose of this study were: 1). Identify the types and culinary potential of Lombok in Lombok, West Nusa Tenggara, as a tourist attraction. This research is descriptive (descriptive research). This approach is used where researchers will describe the results of research on the development of traditional culinary tourism potential as a tourist attraction in Lombok. The location study performed in Lombok, West Nusa Tenggara. In this research, data collection techniques used is a literature study, observation and interviews. Observations and interviews conducted on members of the government that is representative of the Tourism Department of Lombok, Bappeda Lombok, BPOM, academics (representative of the SMIP and AKPAR in Lombok), a cultural, business operators culinary, representatives of travel services businesses (travel), the hospitality industry and the mass media (TV Lombok and local blogger), to determine the potential of culinary tourism owned by Lombok. Based on the survey results revealed that Lombok has a distinctive culinary potential that can be developed into a tourist attraction. Culinary potential possessed Lombok among others. Plecing Kangkung, Ayam Taliwang, Sate Bulayak, Sate Rembiga, Sate Tanjung, Bebalung, BeberukTerong, Nasi Balap Puyung, Ares, Poteng Jaje Tujak and Iwel.
\end{abstract}

\section{Keywords - Culinary Tourism, Tourist Attractions, Lombok}

\section{INTRODUCTION}

Cultural Tourism Development Deputy Ministry of Tourism seeks to increase tourist arrivals, especially in culinary tourism destinations to Lombok. Lombok, West Nusa Tenggara became a heaven for food lovers. Especially spicy food tasteful in accordance with its name the island of Lombok. Culinary one side of the Indonesian culture, born of local knowledge but can move the economy. The traditional food is one of the nation's cultural assets that need to be preserved, in order to maintain their existence / non-existent because civilization and technological progress. Businesses that can be done to maintain the traditional food is by extracting the types of traditional food, then made the development of these foods to be more attractive and desirable without compromising the authenticity of traditional food.

Today, tourism began to adjust to the growing tourist interest and motivation. The tourism sector is rapidly developing culinary tourism. Most of the travelers always taking the time to sample the food and drink typical tourist destination. The term culinary tour are now already familiar in Indonesian society. Many people are starting to take an interest and concern in the culinary world. Culinary tourism is an activity trip or part of these activities are carried out voluntarily and temporary to enjoy a meal or drink (Request Harsana, 2008: 27).

Culinary tourism is one of the dominant Indonesian tourism assets, because of the diversity of culture and agriculture or plantation areas in Indonesia affects the diversity of its cuisine as well. Each region has a different cuisine, so tourists and foreign tourists interested to visit the areas in Indonesia for taking the time to sample the food and drink typical of the region. The traditional food is one of the nation's cultural assets that need to be preserved, in order to maintain their existence / non-existent because civilization and technological progress. Businesses that can be done to maintain the traditional food is by extracting the types of traditional food, then made the development of these foods to be more attractive and desirable without compromising the authenticity of traditional food. Excavation traditional foods can be expected to respond and give a clear picture of the potential of tourism and culinary in Lombok, West Nusa Tenggara in order to increase the attractiveness of the tourist attraction.

\section{Formulation of the problem:}

Identify the types of typical culinary Lombok, West Nusa Tenggara as a potential tourist attraction.

Research purposes:

To determine the types of typical culinary Lombok, West Nusa Tenggara as a potential tourist attraction. 


\section{Literature Review}

\section{Development of Tourist Attractions}

Development is a process or a way to make something be developed, good, perfect, and useful (Suwantoro, 1997: 88-89). Suwantoro (1997: 74) mentions some forms of tourism product alternatives that have the potential to be developed, namely: Cultural tourism, ecotourism, marine tourism, adventure tourism, tourism, agro tourism, village tourism, gastronomy (culinary tourism), spiritual tourism (spiritual tourism) and others.

According Yoeti (1997: 2-3), tourism development needs to consider several aspects to note are:

a. Travellers (Tourist). Must be known characteristics of the traveler, from which country they come, age, hobbies, and in what season they travel. 2) Transportation. Should do research how the transport facilities available to take tourists to the tourist destination in question.

b. Tourist attractions. Attractions and will be sold, whether it meets three requirements such as what can be seen (something to see), what to do (something to do), and what can be purchased (something to buy).

c. Service facilities. What facilities are available at the tourist attraction, how the existing hospitality accommodation, restaurant, public services such as Bank/money changers, post office, telephone/telex in the tourist attraction.

d. Information and promotion. How information about tourist attractions can be well to tourists. The development strategy tourist attraction in this study is how the conscious efforts are being made to develop the existing potential can increase and improve the attractiveness of travel so that the existence of a tourist attraction it more attractive to tourists.

\section{Potential and Travel Attractions}

a. Pendit (1999: 21) explains that the tourism potential are various resources available in a particular area that could be developed into a tourist attraction. In other words, the tourism potential is the variety of resources that are owned by one place and can be developed into a tourist attraction (tourist attraction) that is used for economic interest with regard to other aspects.

b. The appeal or attractions by Yoeti (2002: 5) is everything that can attract tourists to visit at some tourist destinations, such as: (a) Natural attraction: landscape, seascape, beaches, climate and other geographical features of the destinations. (B) Cultural attraction: history and folklore, religion, art and special events, festivals. (C) Social Attractions: the way of life, the resident populations, languages, opportunities for social encounters. (D) Built attraction: building, historic and modern architecture, monuments, parks, gardens, marinas, etc. c. Definition Travel Attractions in accordance with the Law of the Republic of Indonesia No. 10 of 2009 on Tourism Chapter I, Article 5, states as follows: "tourist attraction" is anything that has a uniqueness, beauty, and value the diversity of wealth in the form of natural, cultural and man-made results of the target or destination of tourists visit.

d. Further Cooper et al (1995: 81) argues that there are four (4) components that must be owned by a tourist attraction, namely: 1) Things to Do (Attractions), such as natural attractive, charming local culture and performing arts. 2) Accessibility (accessibilities) such as local transportation and the terminal. 3) Amenitas or facilities (amenities) such as the availability of accommodation, restaurants, and travel agencies. 4) Ancillary services namely tourism organizations needed for tourist services such as destination marketing organization management, conventional and visitor's bureau.

Based on the above exposure to some experts, it can be concluded that the tourist attraction is a formation and/or activity and related facilities as well as be able to attract tourists to come to an area or specific place. The attraction is not yet developed as a potential resource and cannot be called as a tourist attraction to the existence of a certain type of development.

\section{Culinary Tourism}

Culinary tourism is a special interest tours. Culinary is an art that is learned about the food and drinks as well as a wide range of matters relating to food and drink, ranging from the preparation, management, presentation and storage. While the culinary arts is the art of learning about the food and drink that has a specific characteristic of traditional dishes throughout the archipelago (Fadiati in Ariani, 1994: 5).

Wolf in Suriani (2009: 12) states that: "Culinary tourism is not prentious for exlusive. Its includes any unique and memorable gastronomic experience, not just four star restaurant or better rate and include both food and all type of beverages that culinary tourism is not a luxurious and exclusive. Culinary tours emphasis on experience rather than on luxury restaurant or completeness of the types of food and drinks available."

World Culinary Tourism Association (WCTA) in Suriani (2009: 13) states culinary tourism is not new, but related to agro-tourism is more focused on how a food or beverage can attract tourists to enjoy. Culinary tourism can promote gastronomic experience special and memorable (I Putu, 2012).

Culinary tourism is a container that is essential to foster economic growth and development of society and can be found in both urban and rural areas. To help the development of culinary tourism, a food product or beverage to be served in a unique and memorable for travelers. This product can be produced from plantations, agriculture and livestock are treated with a secret recipe that has a specific hereditary and the best flavor (I Putu, 2012).

Culinary tours are part of gastronomic tours where tourists not only meet the need for food and drink but also get 
experience of eating becomes an important value in gastronomic tours. As stated by Ismayanti (2009: 31) "The businesses that appeal culinary cuisine to be driving most of special interest to come to a region".

According to Wolf in Suriani (2009: 13) gives some examples of activities that qualify as culinary appeal, namely:

a. The cooking class or workshop of a food product, in both urban and rural areas.

b. The wine tasting room is interesting, for example, in the old barn.

c. A restaurant in rural areas, which makes the best food so people are willing to drive more than three hours to reach.

To help the development of culinary tourism, a food product or beverage to be served in a unique and memorable for travelers. This product can be produced from plantations, agriculture and livestock are treated with a secret recipe that has a specific hereditary and best flavor.

\section{Traditional food}

The traditional food is a food that most have characteristics which a person is born and grows (Winarno, 1994). More specifically, the concentration of these traditions is characterized, among others:

a. Traditional food consumed by a particular ethnic group in the region.

b. Traditional food more commonly consumed by people who become gorg area which is then introduced to other people or immigrants.

c. Traditional food is prepared to follow the provisions of (prescription) given hereditary. In general, the recipes in traditional food made by the indigenous population is the result of a prescription hereditary and usually more handed down in the family. This is done with the aim that the distinctive flavor of these foods can be maintained.

d. Traditional food made from ingredients obtained locally and presented in accordance with local tastes and traditions. Ingredients to make traditional food can be said to be easy to obtain because basically these materials can be easily bought in markets producing area of traditional foods are usually tailored to the tastes desirable so that there is a traditional food that tasted spicy, sweet, etc.

In the book Knowledge Indonesian Cuisine, Marwanti (112: 2000), there are other opinions that say that the food is traditionally defined as a type of foods commonly consumed by people according to the category tribes and specific areas, based on the following criteria.

a. Calculated according to recipes or food that has been known and applied for generations in the social system of the family or the community.

b. Adapted from materials of food available, both the farm itself or available in the local market. c. The flavor and texture of those foods meet the tastes of family members and the communities concerned.

The characteristics of traditional food by Sosrodiningrat (1991) appears on:

a. Food Recipes obtained from generation predecessor,

b. The use of certain traditional tools in the processing of the food (e.g. food must be processed by means of clay),

c. Mechanical though the cuisine is a way of processing that must be done to get the taste or appearance that is typical of a cuisine.

According to Saka TKK Free SKK and Tourism, the main characteristic of food Indonesia traditionally are:

a. Many contain spices as seasoning,

b. It contains a lot of vegetables,

c. Meat and fish,

d. Sources of vegetable protein is higher than animal protein

The development of culinary in Indonesia is still sporadic for a very wide area and a variety of types other than that there is no single institution that directly fostered by the government with funding that is consistent in conducting research, data collection, counseling, and conducting culinary arts across the region as a cross (Marwanti, 2000).

\section{METHOD}

Based on the variables studied, the type of research is descriptive. The method used in this research is explanatory survey approach used in this research is qualitative research, which is an approach to research that produces descriptive data in the form of words written or spoken of persons or behavior that can be observed. (Moleong, 2002: 3)

This approach is used where researchers will describe the results of research on the development of traditional culinary tourism potential as a tourist attraction in Lombok. The location study performed in Lombok, West Nusa Tenggara. In this research, data collection techniques used is a literature study, observation and interviews Observations and interviews conducted on members of the government that is representative of the tourism department Lombok, Bappeda Lombok, BPOM, academics (representative of the SMIP and Akpar in Lombok), a cultural, business operators culinary, representatives of travel services businesses (travel), the hospitality industry and the mass media (TV Lombok and local blogger), to determine the potential of culinary tourism owned by Lombok.

\section{RESULT}

Lombok Island is known for diversity of traditional food Lombok that have a distinctive taste, which is the main attraction for tourists. Based on observations and interviews conducted on members of the government that is representative of the Tourism Department of Lombok, Bappeda Lombok, BPOM, academics (representative of the SMIP and Akpar in 
Lombok), a cultural, business operators culinary, representatives of the business operators of tourist services (travel), industry hospitality and mass media (TV Lombok and local blogger). There are 10 typical food that has the potential to serve as a unique culinary of Lombok. The culinary tenth among others:

\section{a. Plecing Kangkung}

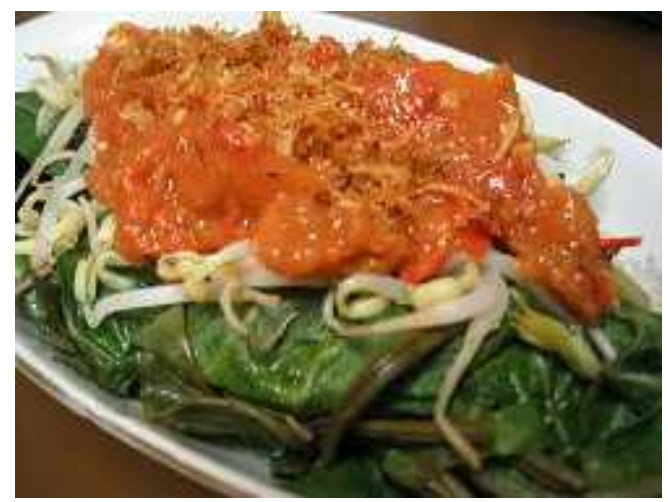

Fig. 1. Plecing Kangkung

Food consisted of boiled morning glory and served with a chili and tomato sauce made from a concoction of cayenne pepper, salt, shrimp paste, and tomato. Location of privileges exist on Lombok morning glory different commonly grown on the island of Java. In the presentation plecing usually added bean sprouts boiled and fried peanuts to neutralize spicy flavor.

\section{b. AyamTaliwang}

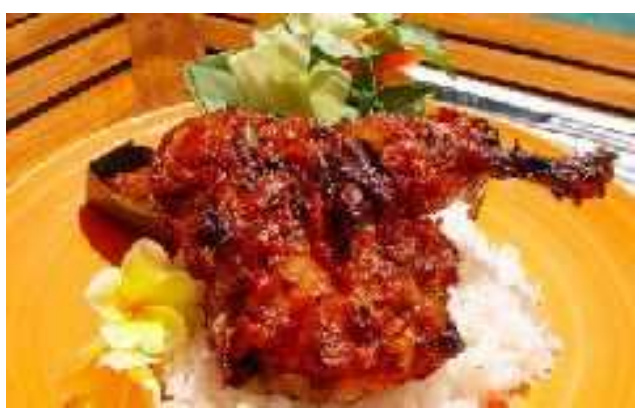

Fig. 2. Ayam Taliwang

Ayam Taliwang usually cooked with several options that are fried, grilled or baked. Will be more delicious if you use chicken with chicken young age. Taliwang chicken delicacy is also located in a spicy marinade. Seasoning paste and the type of young chickens that are used to make this dish has excellent taste.

\section{c. Sate Bulayak}

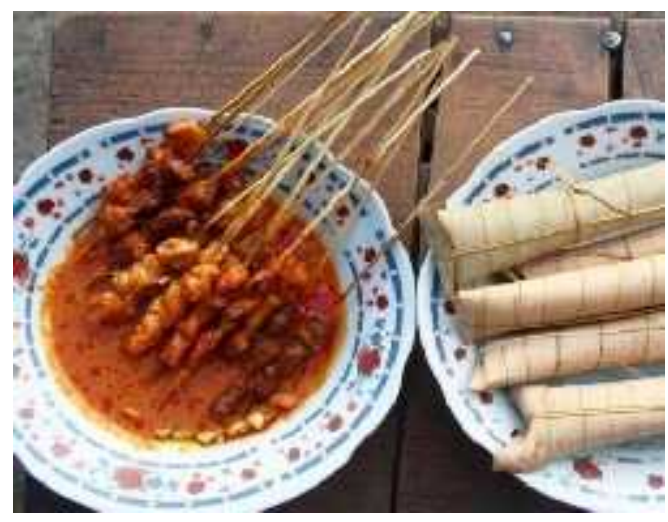

Fig. 3. Sate Bulayak

Sate Bulayak made from offal and beef seasoned with herbs Sasak and burned using shells or coconut fiber. Unlike the Sate Rembiga, this satay served with a sauce made from ground peanuts and boiled with other spices, such as garlic, coriander, chili. Savory seasoning sauce, curry-like sauce. Another unique thing of this sate is complementary, ie bulayak. Bulayak is a type of rice cake wrapped in palm leaves or palm wrapped around in a circle. Bulayak has a softer texture and aroma of palm leaves.

\section{d. Sate Rembiga}

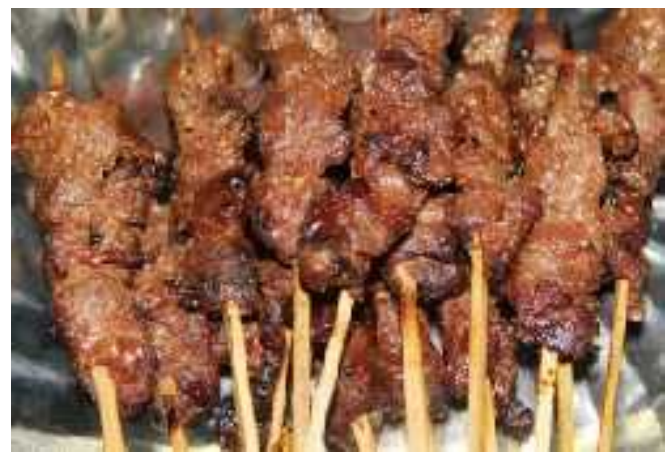

Fig. 4. Sate Rembiga

Sate Rembiga made of meat or offal, diced and then soaked in a mixture of onions, cayenne pepper, sugar, pecans and do not miss the shrimp paste, as well as some other spices. During this soaking process, the meat is stirred periodically to allow the flavors to seep evenly, in addition, the resulting meat will be tender. Sate presented simply without sauce or seasoning nuts, because the meat skewers already rich in herbs and spices flavored sweet savory. 


\section{e. Sate Tanjung}

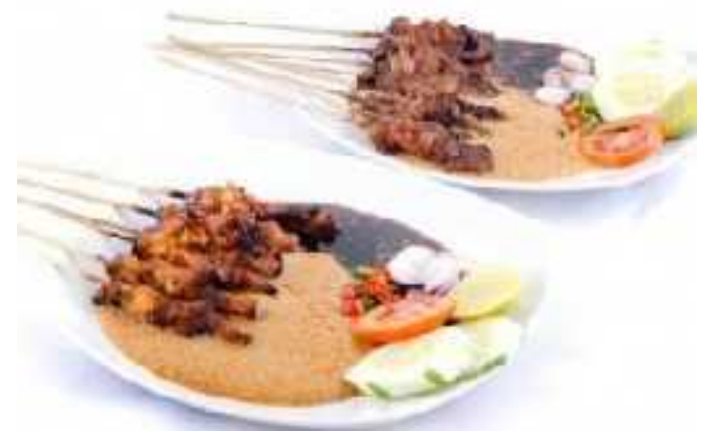

Fig. 5. Sate Tanjung

Unlike the sate rembiga made from beef, satay cape comes from skipjack or fish Langoan. Savory taste of meat and coconut milk and spicy of spices are felt when enjoying sate tanjung.

\section{f. Bebalung}

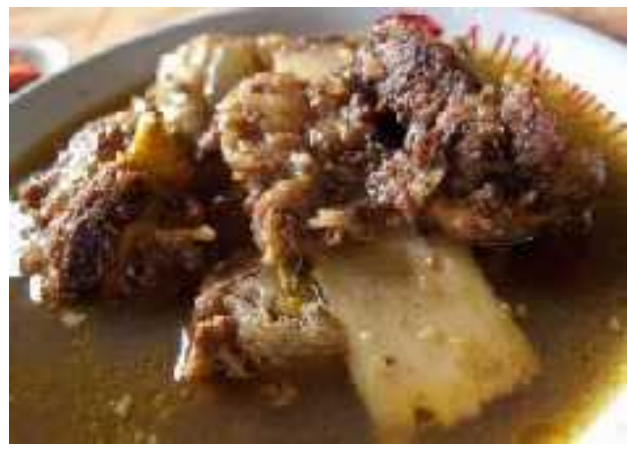

Fig. 6. Bebalung

Bebalung is typical food Lombok form of soft beef rib soup, cooked with spice concoction consisting of cayenne pepper, garlic, onion, ginger and turmeric, and ginger to be extra spicy and hearty taste can be mixed in the dish. Warm spicy taste is more complete with additional salt and acid that gives a fresh sensation, also make cooking more durable. This spice blend called ragi rajang by the Sasak people.

\section{g. Beberuk Terong}

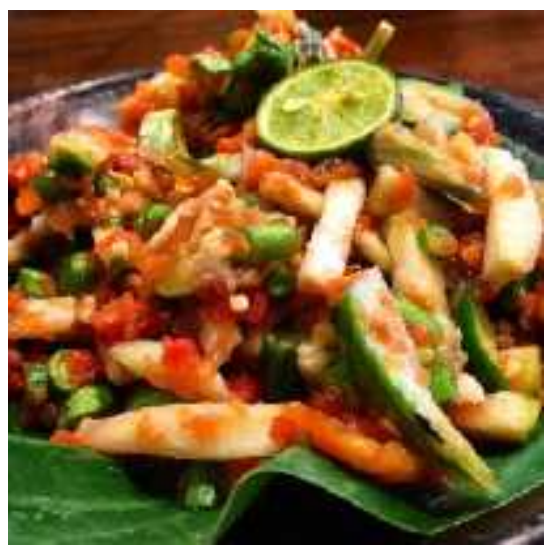

Fig. 7. Bebek Terong

Beberuk is a kind of sauce with mixed raw vegetables are usually served as a complement to grilled chicken dishes taliwang. The main ingredient of beberuk is purple eggplant cut into small pieces, cubes. While the tomatoes can be cut into pieces and mixed with eggplant or used as a seasoning sauce mashed together with peppers, onions, kencur, grilled shrimp paste, salt, sugar and cooking oil. As an aroma enhancer can be added lemon juice and basil.

\section{h. Nasi Balap Puyung}

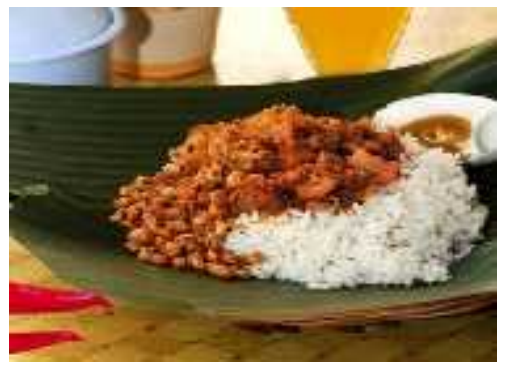

Fig. 8. Nasi Balap Puyung

Nasi balap puyung has spicy flavor, as well as typical food Lombok sharing. A sprinkling of nuts, both soybeans and peanuts also aims to neutralize and slightly reduce the spicy taste of spicy shredded chicken and vegetables mixed with rice.

\section{i. $\quad$ Ares}

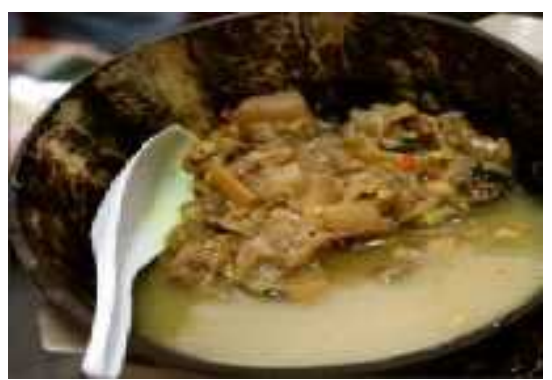

Fig. 9. Ares 
Ares is typical vegetable Lombok is the main ingredient comes from the stem of banana or gedebok. Taste the dishes that use coconut milk which is quite unique sweet and savory. Initially ares is a traditional Sasak and food served at the wedding to the then popular become typical food Lombok. Ares is more delicious when eaten while still warm with a plate of white rice.

\section{j. Poteng Jaje Tujak dan Iwel}

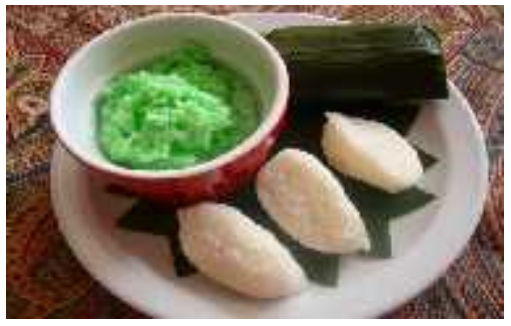

Fig. 10. 10 Poteng Jaje Tujak and Iwel

Poteng Jaje Tujak and Iwel is a typical food Lombok during Eid. This dish consists of two foods that Poteng or fermented rice and Jaje Tujak or Tetel (steamed glutinous rice). Besides Poteng Jaje Tujak, there Iwel which is typical snacks of local communities. Iwel is a cake made from black rice is usually served at the ceremony local tradition, has a sweet taste. Now Poteng Jaje Tujak and Iwel can be enjoyed not only on the big day only.

Based on the above presentation, it is known that Lombok has ten distinctive culinary potential that can be developed into a tourist attraction attractions. Potential of culinary tourism is not enough to serve as a tourist attraction, if it does not meet aspects of supporting the existence of a tourist attraction, such as the availability of accessibility such as local transportation and the conditions of access to the tourist attraction, the availability amenitas or facilities such as the availability of accommodation, restaurants, and travel agents, and ancillary services, namely tourism organizations needed for tourist services such as destination marketing organization management, conventional and visitors bureau. Based on observations and interviews it is known that, some chili culinary potential have limitations in the supply of raw materials. As in culinary Plecing Kangkung, which require different types of morning glory produced by other regions. Specific raw material requirements that are not supported by the availability of materials, which are now not much generated due to limited number of farmers who grow this vegetable and land use, because they do not generate huge profits.

In developing destinations Lombok as tourism, the role of local communities need to be involved, it is expected that people can create a strong commitment to make the Lombok as a destination for a safe and comfortable place to visit. The benefits from the presence of tourists is expected to be felt by the community, so they will choose to develop all its potential to be developed into a product Lombok travel.

The government also needs to meet the accommodation needs of travelers, such as the availability of hotels and restaurants that meet good standards that are intended for tourist arrivals. The availability of good transport accessibility, information and infrastructure need to be prepared, so that visitors can access tourist attraction owned Lombok from easy.

The role of the organization of tourism is also important, which is managing a tourist attraction that has value and can take place on an ongoing basis, providing clear information about the appeal of which is owned Lombok so that the wealth of Lombok tourism can be known to tourists and foreign tourists, providing guide and travel agent so that tourists can do tourist activity comfortably with the help of a trusted travel tour operators

\section{CONCLUSION}

Based on the survey results revealed that Lombok, West Nusa Tenggara typical culinary potential that can be developed into a tourist attraction. Culinary potential possessed Lombok among others. Plecing Kangkung, Ayam Taliwang, Sate Bulayak, Sate Rembiga, Sate Tanjung, Bebalung, BeberukTerong, Nasi Balap Puyung, Ares, Poteng Jaje Tujak and Iwel. In general, seasoning Sasak not be separated from the use of chili and shrimp paste. Shrimp paste used is Lengkare with more savory and sweet flavors. Paste that has a pungent smell is present in a variety of dishes typical of Lombok, Sasak Another characteristic of the cuisine is the use peanut or soy, spicy flavor with spices coriander and lemongrass dominates. Not only the main meal, Lombok also has a lot of variety of snacks. Traditional pastries Lombok has much in common with traditional pastries in Java, just different names. Raw materials that dominate traditional pastries on the island of Lombok is sticky rice and corn, it is because the natural products that are produced on the island of Lombok.

a. Based on observations and interviews it is known that, some chili culinary potential have limitations in the supply of raw materials, because raw material supply business backers culinary efforts deemed not generate huge profits. Therefore develop Lombok as a tourist destination, the role of local communities need to be involved, it is expected that public participation can create a strong commitment to make the Lombok as a tourist destination that is safe and comfortable place to visit. The benefits from the presence of tourists is expected to be felt by the community, so they will choose to develop all its potential to be developed into a product Lombok travel. The government also needs to meet the accommodation needs of tourists, and increase the role of the organization of tourism so that tourists can travel comfortably perform activities with the help of a trusted travel tour operators.

\section{REFERENCES}

Ariani, R.P. (1994). Studi Kelayakan Seni Kuliner Bali Mengenai HidanganTradisional Propinsi Bali. Laporan Penelitian. Singaraja: STKIP.

Frone, M. R, Russell, M., \& Cooper, M. L. (1992). Antecedents and outcomes of work- family conflict: Testing a model of the work-family interface. Journal of Applied Psychology, 77(1), 65-78. 
I Putu Gede Parma. (2012). Formulasi strategi pengembangan Masakan lokal sebagai Produk Wisata Kuliner di Kabupaten Buleleng. Kajian.

Ismayanti. (2009). Pengantar Pariwisata. Jakarta: Grasindo.

Lexy J Moleong, 2002. Metode Penelitian Kualitatif. Bandung: PT. Remaja Rosdakarya.

Marwanti. 2000. Pengetahuan Masakan Indonesia. Cetakan Pertama. Yogyakarta: Adicita Karya Nusa.

Pendit, Nyoman S. 1999. Ilmu Pariwisata. PT. Pradya Pratama. Jakarta.

Suriani, Ni Made. 2009. Seni Kuliner Bali sebagai Salah Satu Daya Tarik Wisata Studi Kasus di Warung Babi Guling
Ibu Oka di Kelurahan Ubud, Gianyar, Bali. Program Studi Magister (S2) Kajian Pariwisata. (Tesis). Denpasar: Universitas Udayana.

Suswantoro. 2007. Dasar-Dasar Pariwisata. Yogyakarta. Penerbit Andi Offset.

Surakhmad, Winarno. 1994. Pengantar Penelitian Ilmiah. Bandung: Tarsito.

Undang-Undang Dasar No. 10 Tahun 2009 Tentang Kepariwisataan.

Yoeti, Oka A., 1997, Tours And Travel Management, Jakarta: PT Pradnya Paramita 